https://doi.org/10.37208/tgn27303

\section{Herring gull (Larus argentatus) damage to razor clam (Ensis siliqua and $E$. ensis) shells on the Isle of Cumbrae, Scotland}

\author{
P.G. Moore \\ 32 Marine Parade, Millport, Isle of Cumbrae KA28 0EF \\ E-mail: p.geoff.moore@gmail.com
}

Herring gulls (Larus argentatus) are an opportunist species with a catholic diet (Tinbergen, 1953; Hudson \& Furness, 1988; Ewins et al., 1994; Moore, 2018). They have been reported feeding on razor clams (Ensis leei, as "E. directus") in the Dutch Wadden Sea (Cadée, 2000; Enners et al., 2018). Witnessing them feeding on E. siliqua and E. ensis near my house in Millport, Isle of Cumbrae, Scotland (NS171547) in April 2020 provided the opportunity for comparative observations.

Both razor clam species are common in sublittoral sand below the adjacent beach at Kames Bay, Millport (Allen, 1962; see Holme, 1951 and Fig. 1 herein for distinguishing features). Herring gulls were seen feeding on both Ensis species at three sites: (1) the grass verge in front of my house (this observation being subsequent to my previously finding at the same site dead shells - mostly still articulated - that were below the line of flotsam thrown up on the grass and so had clearly not been deposited by recent storms); (2) a rocky prominence on the seaward side of the nearby boating pond; and (3) the tide edge during suitable low-tide conditions on the south-east corner of Kames Bay. Ensis shells were recovered from all three places from 12 th to 22nd April (daily, or when tidally appropriate) and the collection examined for signs of shell damage. It was hoped that damage patterns might provide insight into how herring gulls at this location feed on razor clams.

On 12th April, 11 E. siliqua and two E. ensis empty shells were collected along a $70 \mathrm{~m}$ length of the grass verge; on 21st April nine E. siliqua and five E. ensis shells were collected from the rocky prominence (where they were accompanied by broken sea urchin (Echinus esculentus) tests and considerable guano splattering), and five E. siliqua and one E. ensis shells were collected from the tide-edge at low tide on the beach but over what period the accumulations had taken place at the first two sites is unknown. The first two sites represented preferred food-processing stations (vigilance posts?) but whether of particular gulls is unknown. One reason why Ensis shells might be processed at sites away from the beach became apparent when a herring gull feeding on a newly extracted razor clam at the tide edge

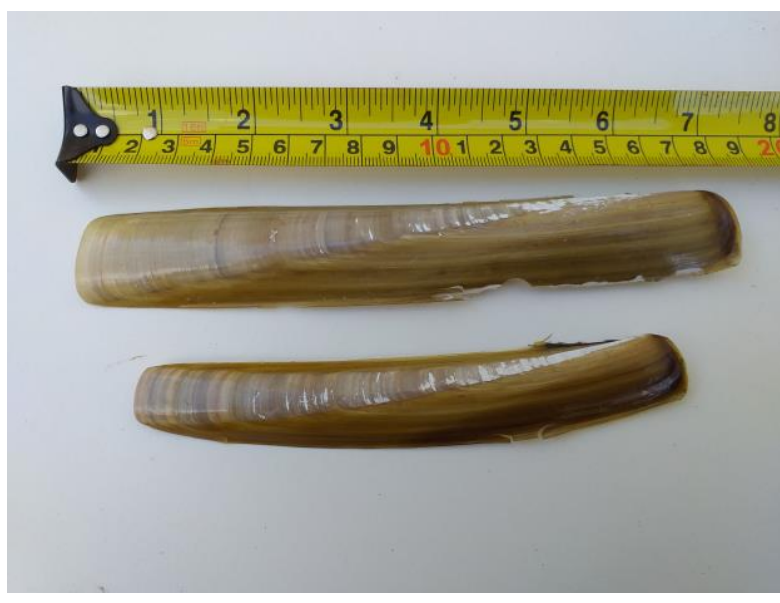

Fig. 1. Right valves of the razor clams Ensis siliqua (top) and $E$. ensis (bottom) from Isle of Cumbrae, Scotland. Note relative sizes and robustness. (Photo: P.G. Moore)

was harassed by a great black-backed gull (L. marinus) landing alongside it, which was followed by the herring gull flying away with the shell. The herring gulls' initial tendency to open shells at the immediate tide edge would account for sand grains becoming adherent to flesh fragments found remaining stuck to the inside of the recovered empty shells.

Most empty shells were orientated with their internal surfaces facing up and the majority ( $96 \%$ of $E$. siliqua and $87 \%$ of E. ensis) remained articulated. None was deposited on the adjacent hard surface either of the adjacent road (Marine Parade) or pavement, suggesting that the gull (or gulls) that had acquired this proclivity was/were not dropping the shells from a height onto a hard surface in order to break the shells. Similarly on the rocky prominence few shells were smashed. Ensis shells are quite brittle so it would be easy to break them in the way that gulls treat other prey items such as mussels (Mytilus spp.), sea urchins (Echinoidea) and hermit crabs (Paguridae) (see Moore, 2018), but this seems not to have occurred. Occasional crushed shells were found on hard surfaces around the boating pond (pond-edge walkway, iron man-hole cover) but were most likely the result of children stamping on intact shells.

Dutch herring gulls in the Wadden Sea were able to access razor clams in $<40 \mathrm{~cm}$ of water by up-ending and seizing the clams' posterior protrusions (Cadée, 2000). Cadée described a characteristic pattern of shell fragmentation of $E$. leei resulting from such predation, caused by the gull shaking the extracted razor clam vigorously after gripping the shell at about the shell's middle, with no hammering involved. Both valves were typically damaged medially as a result, although about a quarter of the shells remained undamaged.

On Cumbrae, E. siliqua (Fig. 2) damage was most often $(28 \%)$ associated with the first quartile of the ventral margin of the right valve (the shell ligament being anatomically "anterior dorsal"). In the pooled sample of 
25 E. siliqua shells, accumulated between 14th and 22nd April (consistent with tidal conditions) from all three sites, ten $(40 \%)$ were undamaged, whilst in damaged shells the damage sustained was focused in the anterior quartiles of the shell (Fig. 2; Table 1). This corresponds with the position of the anterior adductor muscle (see Yonge \& Thompson, 1976: Figs. 113, 115), the rupture of which would allow swift access to the razor-clam tissue by facilitating shell gape (E. leei razor clam flesh is consumed in one or two minutes according to Cadée (2000)). Perhaps because E. siliqua is a larger, more robust species its shells suffered less damage than reported for E. leei. The size of the fracture (Fig. 2) suggests a strike or a snip with the gull's bill (bill width ca. $20 \mathrm{~mm}$; Bob Furness, pers. comm.). It is notable that damage was principally sustained by the right valve (Fig. 2; Table 1) and only one E. siliqua shell had both valves damaged. It may be relevant that Feare (1971) showed that oystercatchers exhibited a "right-handed" tendency in the way they prised limpets (Patella aspera) off rocks.

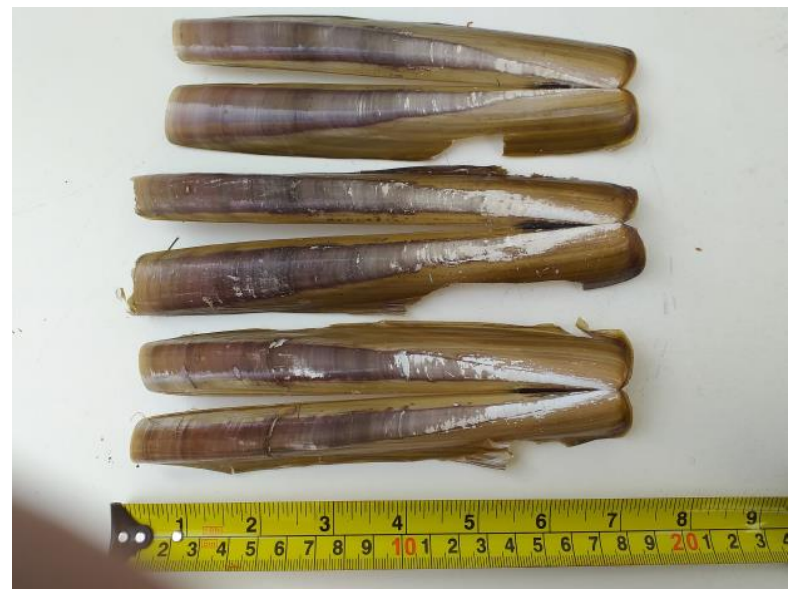

Fig. 2. Damage to the first quartile of the ventral margin of the right valves of three razor clams (Ensis siliqua) from Isle of Cumbrae, Scotland. (Photo: P.G. Moore)

Of the smaller E. ensis shells (see Holme, 1951 and Fig. 1) that were recovered $(\mathrm{N}=8), 50 \%$ were undamaged (Table 1). Other individuals had damage extending further along the ventral margins of both valves, suggesting that vigorous shaking by the gull, resulting in damage about the middle of the shell, might characterise the herring gull's processing of E. ensis, at least locally, but might not apply to E. siliqua. Extraction of the clam from the substratum by gripping the siphons or the posterior margin of the shell might account for the "nibbles" to that margin noted in two $E$. siliqua specimens (Fig. 3), but I have yet to observe a complete cycle of razor shell capture and a gull's initial clam flesh-accessing behaviour.

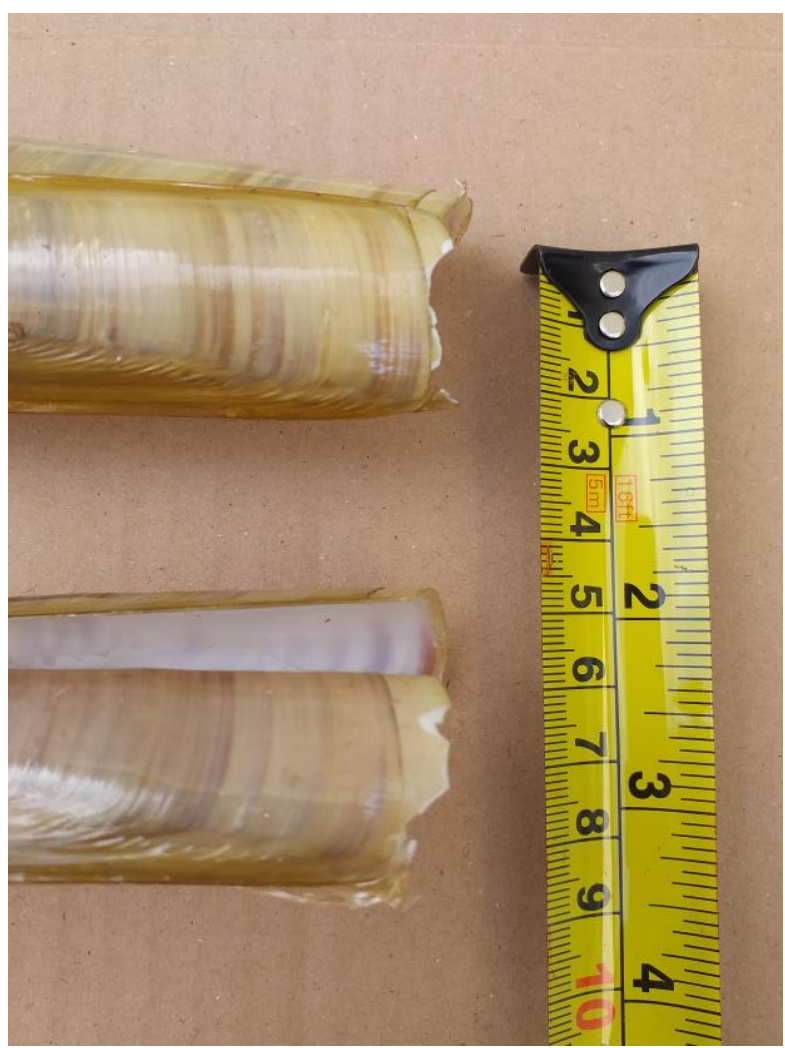

Fig. 3. Damage to the posterior shell margins of the left valves in two razor clam (Ensis siliqua) specimens from Isle of Cumbrae, Scotland. (Photo: P.G. Moore)

\begin{tabular}{lllll}
\hline & \multicolumn{2}{l}{ Ensis siliqua } & \multicolumn{2}{l}{ Ensis ensis } \\
\cline { 2 - 5 } & $\begin{array}{l}\text { Right valve damage: } \\
\text { N (\%) }\end{array}$ & $\begin{array}{l}\text { Left valve damage: } \\
\text { N (\%) }\end{array}$ & $\begin{array}{l}\text { Right valve damage: } \\
\text { N (\%) }\end{array}$ & $\begin{array}{l}\text { Left valve damage: } \\
\text { N (\%) }\end{array}$ \\
\hline 1st quartile & $7(28)$ & $4(16)$ & 0 & 0 \\
2nd quartile & $4(16)$ & $4(16)$ & $2(25)$ & $2(25)$ \\
3rd quartile & $1(4)$ & $4(16)$ & $3(38)$ & $2(25)$ \\
4th quartile & 0 & $2(8)$ & 0 & 0 \\
\hline
\end{tabular}

Table 1. Summary of damage to razor clam Ensis siliqua $(\mathrm{N}=25)$ and E. ensis $(\mathrm{N}=8)$ shells from sites at Kames Bay, Isle of Cumbrae, Scotland, April 2020. 


\section{REFERENCES}

Allen, J.A. (1962). Fauna of the Clyde Sea Area. Mollusca. Scottish Marine Biological Association, Millport.

Cadée, G.C. (2000). Herring gulls feeding on a recent invader in the Wadden Sea, Ensis directus. Geological Society of London Special Publication 177, 459-464.

https://doi.org/10.1144/GSL.SP.2000.177.01.31

Enners, L., Schwemmer, P., Corman, A.-M., Voigt, C.C. \& Garthe, S. (2018). Intercolony variations in movement patterns and foraging behaviours among herring gulls (Larus argentatus) breeding in the eastern Wadden Sea. Ecology and Evolution 8, 7529-7542.

https://doi.org/10.1002/ece3.4167

Ewins, P.J., Weseloh, D.V., Groom, J.H., Dobos, R.Z. \& Mineau, P. (1994). The diet of herring gulls (Larus argentatus) during winter and early spring on the lower Great Lakes. Hydrobiologia 279, 39-55. https://doi.org/10.1007/BF00027839

Feare, C.J. (1971). Predation of limpets and dogwhelks by oystercatchers. Bird Study 18, 121-129. https://doi.org/10.1080/00063657109476305

Holme, N.A. (1951). The identification of British species of the genus Ensis Schumacher (Lamellibranchiata). Journal of the Marine Biological Association of the United Kingdom 29, 639-647. https://doi.org/10.1017/S0025315400052838

Hudson, A.V. \& Furness, R.W. (1988). Utilization of discarded fish by scavenging seabirds behind trawlers in Shetland. Journal of Zoology 215, 151166.

https://doi.org/10.1111/j.1469-7998.1988.tb04890.x

Moore, P.G. (2018). On the paddling behaviour of a herring gull. The Glasgow Naturalist 26(4), 89-90.

Tinbergen, N. (1953). The Herring Gull's World: a Study of the Social Behaviour of Birds. Collins, London.

Yonge, C.M. \& Thompson, T.E. (1976). Living Marine Molluscs. Collins, London. 